\title{
Molecular phylogeny of orchids mycorrhiza isolated from native tropical orchids in Indonesia
}

\author{
Mahfut $^{1}$, Ari Indrianto², Susamto Somowiyarjo ${ }^{3}$ and Budi Setiadi Daryono ${ }^{2 \star}$ \\ ${ }^{1}$ Department of Biology, Faculty of Mathematics and Natural Sciences, Universitas Lampung, Lampung, 35145, \\ Indonesia. \\ ${ }^{2}$ Department of Biology, Faculty of Biology, Universitas Gadjah Mada, Yogyakarta, 55281, Indonesia. \\ ${ }^{3}$ Department of Virology, Faculty of Agriculture, Universitas Gadjah Mada, Yogyakarta, 55281, Indonesia. \\ Email: bs daryono@mail.ugm.ac.id
}

Received 8 April 2019; Received in revised form 17 June 2019; Accepted 6 August 2019

\begin{abstract}
Aims: Mycorrhiza has an important role as a biocontrol agent. Its association with Phalaenopsis amabilis was molecularly identified through rDNA-ITS sequence analysis. The aims of the study were to identify molecular of orchids mycorrhiza isolate from native tropical orchids in Indonesia, conducted as one of native orchid conservation efforts in Indonesia.

Methodology and results: One group of Ceratobasidium were isolated from the root of orchid plant in Yogyakarta based on morphological and microscopical analysis. The results of molecular analysis showed 600-750 bp of DNA products located on the ITS1-5.8S-ITS4 region. The sequenced products showed insertion and substitution occurances, which may result in strain diversity and possible variation. Reconstruction of phylogenetic trees using Maximum Parsimony and Bootstrap-1000 approach showed showed the Indonesian isolate is at the basal clade and already far apart from the other isolates.

Conclusion, significance and impact of study: Isolate Ceratobasidium from Yogyakarta, Indonesia successfully isolated based on identification of rDNA-ITS sequences. Results of this study were expected to become the basic information in an effort of native orchid cultivation and protection against infectious diseases in Indonesia. The study was the first to report regarding Ceratobasidium isolated from native tropical orchids in Indonesia.
\end{abstract}

Keywords: Ceratobasidium, rDNA-ITS, Phalaenopsis, Indonesia

\section{INTRODUCTION}

Phalaenopsis is a genus of orchids, which some of its members have important role as parent crosses. Approximately 30 of the total 62 species are spread throughout Indonesia. The presence of this genus in its native habitat (nature) has been reported to have greatly diminished, even some of the members have been recorded to the IUCN red list version 2013.2 due to excessive exploration and forest degradation. Thus, it is very necessary to conserve the existence of native Phalaenopsis orchids in Indonesia through the efforts of preservation and protection of plants.

Infections by bacteria, fungi, and viruses are still major obstacles in conducting cultivation and development of native orchids in Indonesia (Kumalawati et al., 2011; Mahfut and Daryono, 2014; Mahfut et al., 2016; Daryono et al., 2016; Mahfut et al., 2017; Mahfut et al., 2019b). Cultivating and protecting Phalaenopsis sp. against diseases in Indonesia could be done through the induction of endophytic microorganisms (Tanawy, 2009), which includes the Orchid Mycorrhizal Fungi (OMF). Endophytic microorganisms are biological agents that can prevent and reduce the severity of disease caused by infectious pathogens by producing enzymes and secondary metabolites that are antagonistic (Harish et al., 2008), which in addition can also help the growth and development of plants. One type of OMF which have been isolated and identified is Ceratobasidium.

Ceratobasidium could induce the resistance of Phalaenopsis sp. against infections by Erwinia chrysanthemi causing soft root disease (Wu et al., 2011), fungal infection by Fusarium sp. causing rotten stems, leaves, and shoots, as well as inhibit the replication Odontoglossum ringspot virus (ORSV) and Cymbidium mosaic virus (CymMV). In addition for playing a role as biological control agents in crop protection (Otero et al., 2013), OMF has a role in stimulating the germination of orchid seeds and helping the establishment of more buds and flowers (Andersen et al., 1996; Moreno et al., 2000; 
Wu et al., 2011; Mahfut et al., 2019a). In this research, the identification of Ceratobasidium was molecularly conducted through analysis of rDNA-ITS sequence isolated from $P$. amabilis grown in Indonesia. This research was expected to become the basic information on the development of cultivation and protection of nature orchids and where possible, on the prevention of the occurence of the mentioned diseases in Indonesia.

\section{MATERIALS AND METHODS}

\section{Plants materials}

The sampling of healthy roots of $P$. amabilis was conducted at four different locations: orchid garden in Condong Catur and Parakan (Yogyakarta), Balikpapan Botanical Garden (East Kalimantan), and Sultan Adam Forest (South Kalimantan).

\section{Molecular analysis}

Genomic DNA isolation was performed using techniques modified from cetyltrimethylammonium bromide (CTAB) method (Doyle and Doyle, 1987; Weiland, 1997) on samples of pure cultures of isolated mycorrhizal endophyte Ceratobasidium. Genomic DNA was PCR amplified according to the manual instructions of GoTaq ${ }^{\circledR}$ Green PCR mix (Promega). Predenaturation reaction and amplification was carried out using methods by Nadarajah et al. (2014), with a pair of universal primers, rDNA-ITS1 (5'-TCCGTAGGTGAACCTGCGG-3') and rDNA-ITS4 (5'TCCTCCGCTTATTGATATGC-3'). PCR products were visualized using electrophoresis on $2 \%$ agarose gel stained with ethidium bromide and 100 bp Vivantis DNA ladder was used as marker. The visualized DNA bands indicated the length of the targeted base pairs of rDNAITS, which were subjected to sequencing.

\section{Phylogenetic analysis}

Sequencing results were analyzed using Sequence Scanner software; the nucleotide sequences were combined using EditSeq and SeqMan of the Software Suite for Sequence Analysis DNASTAR Lasergene DM Version 3.0.25. BLAST software was used to determine and to compare the sequence homology with the data contained in the DDBJ database. Comparation between sequences of isolates was carried out using Algorithm Multiple Alignment Parameters DNA with Kimura-2 Parameters, relationship and phylogenetic analysis using the Neighbour Joining of MEGA 5 Beta program. Statistical analysis on internal branch was done using the bootstrap value with 1000 replication.

\section{RESULTS}

\section{Sample collection}

A total of 12 samples of healthy roots of $P$. amabilis were isolated from 4 different locations, such as orchid garden in Condong Catur and Parakan (Yogyakarta), Balikpapan Botanical Garden (East Kalimantan), and Sultan Adam Forest (South Kalimantan). One positive sample of Ceratobasidium was found from orchid garden in Parakan (Figure 1), which had colony characteristic traits i.e. yellowish to white color, colony appearance like a cotton, $90^{\circ}$ branching hyphae shape, binucleate, with colony growth rate of $0.72 \mathrm{~mm} / \mathrm{h}$, referring to Currah and Zelmer (1992) and Shan et al. (2002).

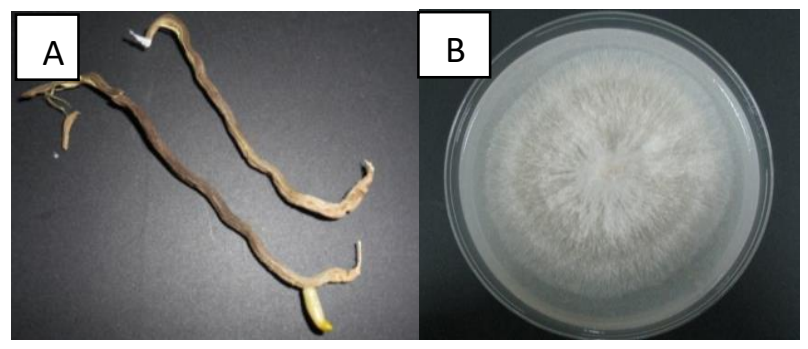

Figure 1: Sample collections of root of $P$. amabilis orchid (A) and Ceratobasidium isolate (B) from Parakan (Yogyakarta). Bar size $1 \mathrm{~cm}$.

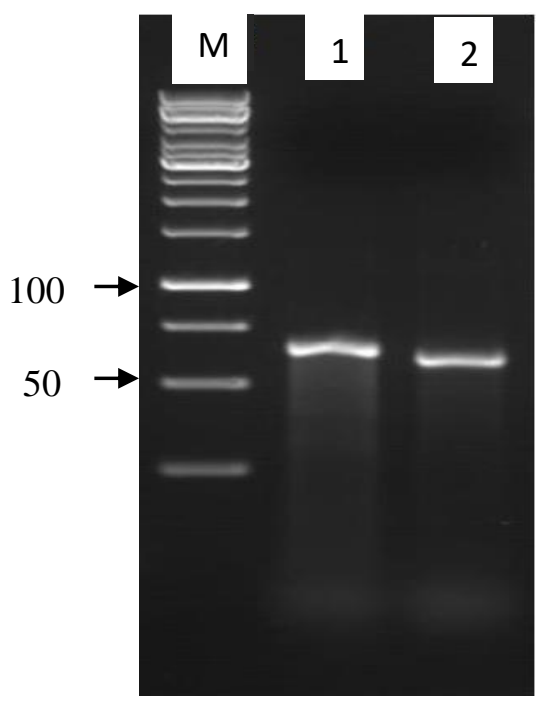

Figure 2: Results of ITS rDNA amplification on endophyte mycorrhizae Ceratobasidium; $M=$ Marker (1 kb), 1 and 2 = Mychorrizae Parakan (MP)

\section{Molecular analysis}

ITS rDNA amplification results showed a specific band with a size between 600 and 750 bp (Figure 2) similar to that reported by Johansson et al. (1998), Nadarajah et al. (2014) and Pannecoucque et al. (2008). Internal transcribed spacer (ITS) is an area of the nuclear ribosomal DNA ( $\mathrm{nrDNA})$, which has the role of providing important information on the reconstruction of phylogenetic trees at different taxonomic levels (Bayer et al., 1996), as well as similarity at the level of intrageneric (Lee et al., 2010). 
Malays. J. Microbiol. Vol 161) 2020, pp. 68-72

DOI: http://dx.doi.org/10.21161/mjm.190425

\begin{tabular}{|c|c|c|c|c|c|c|c|c|c|c|c|c|c|c|c|}
\hline$\%$ & 1 & 2 & 3 & 4 & 5 & 6 & 7 & 8 & 9 & 10 & 11 & 12 & 13 & 14 & 15 \\
\hline 1 & 100 & & & & & & & & & & & & & & \\
\hline 2 & 99.4 & 100 & & & & & & & & & & & & & \\
\hline 3 & 99.5 & 99.5 & 100 & & & & & & & & & & & & \\
\hline 4 & 99.7 & 99.7 & 99.8 & 100 & & & & & & & & & & & \\
\hline 5 & 99.7 & 99.4 & 99.5 & 99.7 & 100 & & & & & & & & & & \\
\hline 6 & 100.0 & 99.5 & 99.7 & 99.8 & 99.8 & 100 & & & & & & & & & \\
\hline 7 & 99.5 & 99.2 & 99.7 & 99.7 & 99.5 & 99.7 & 100 & & & & & & & & \\
\hline 8 & 96.6 & 99.4 & 99.5 & 99.6 & 96.3 & 99.8 & 96.5 & 100 & & & & & & & \\
\hline 9 & 99.8 & 99.7 & 99.8 & 100.0 & 99.7 & 99.8 & 99.8 & 98.7 & 100 & & & & & & \\
\hline 10 & 99.7 & 99.7 & 99.8 & 100.0 & 99.7 & 99.8 & 99.8 & 96.6 & 100.0 & 100 & & & & & \\
\hline 11 & 99.5 & 99.5 & 99.7 & 99.9 & 99.5 & 99.7 & 99.6 & 96.5 & 99.8 & 99.8 & 100 & & & & \\
\hline 12 & 99.5 & 99.5 & 99.7 & 99.9 & 99.5 & 99.7 & 99.6 & 96.5 & 99.8 & 99.8 & 99.7 & 100 & & & \\
\hline 13 & 99.8 & 99.2 & 99.7 & 99.9 & 99.8 & 100.0 & 99.3 & 97.2 & 99.8 & 99.8 & 99.4 & 99.7 & 100 & & \\
\hline 14 & 99.8 & 99.7 & 99.8 & 100.0 & 99.7 & 99.8 & 99.8 & 987 & 100.0 & 100.0 & 99.8 & 99.8 & 99.8 & 100 & \\
\hline 15 & 46.7 & 46.5 & 46.9 & 46.7 & 46.8 & 46.6 & 45.2 & 46.1 & 46.7 & 45.7 & 46.5 & 46.9 & 45.3 & 46.7 & 100 \\
\hline
\end{tabular}

Figure 3: Matrix of similarity level percentage of the obtained Ceratobasidium sp. nucleotide sequences analyzed using DNASTAR Lasergene program DM Version 3.0.25. \%: Percentage of Identity; 1: Singapore2; 2: Spain; 3: Taiwan; 4: America; 5: Argentina; 6: Netherland; 7: China; 8: Cuba; 9 : India; 10: Singapore; 11: Iran; 12: Israel; 13: Italy; 14: Japan; 15: Indonesia.

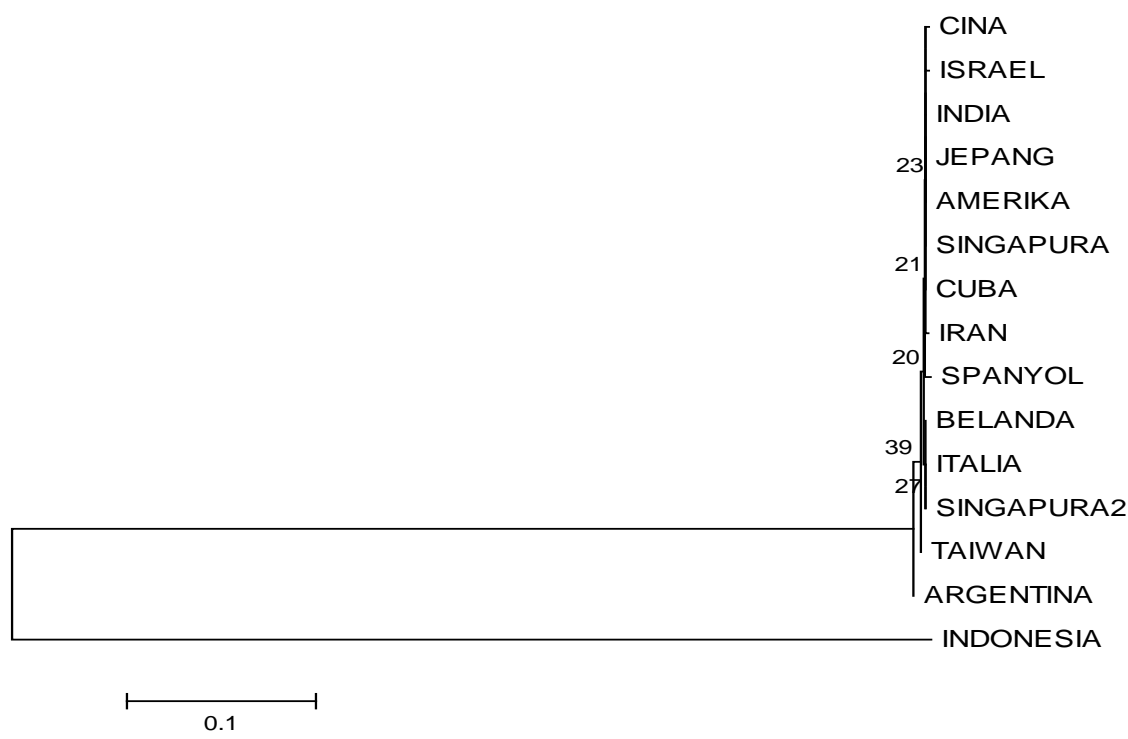

Figure 4: Reconstruction of phylogenetic trees of Ceratobasidium sp. isolates based on nucleotide sequences with Maximum Parsimony method with Bootstrap-1000 approach.

Sequencing results were analyzed using DNASTAR Lasergene DM Version 3.0.25. Total number of nucleotides of MP isolates which succesfully scanned was 661 with $41.4 \%$ GC content. Analysis results were obtained by incorporating sequences to http://blast.ncbi.nlm.nih.gov/ site and confirmed that MP isolates were Ceratobasidium. Sharon et al. (2008) explained that mychorriza in the anamorphic classification is divided into 3 main categories: multinucleate (teleomorphs: Thanatephorus and Waitea), binucleate (teleomorphs: Ceratobasidium and Tulasnella), and uninucleate (teleomorph: Ceratobasidium). Based on microscopic observation, MP isolates were found to be binucleate (data not shown). Furthermore, analysis search of homologous sequences carried out using BLAST on NCBI site resulted in 47 sequences indicating a close relationship with high level of similarity of $99 \%$. This result showed that the MP sequences are representative of Ceratobasidium sp. isolates, a nonpathogenic (endophyte) associating with the root of orchid (OMF).

All isolates were chosen and compared from various countries in Asia (Israel, China, Taiwan, Japan, Iran, Singapore and India), America (US, Cuba, and Argentina), and Europe (Italy, the Netherlands, and Spain). Some isolates of Ceratobasidium, was collected from the roots of Vanda miss Joaquim (AJ318420) and Brite $\mathrm{Ng}$ (AJ318429) orchids, and also from the roots of 
other plants such as Rosa hybrida cv. Linda (KC825348), strawberry Fragaria $x$ ananassa (AY927319) and apples (EU002945.1). Total bases amplified from each isolate ranged from 560 to $725 \mathrm{bp}$, except from DQ097889.1 isolate with a total amplified base of $1500 \mathrm{bp}$. Maximum BLAST score between isolates ranged from 1005 to 1186 with homology (ident.) $99 \%$ and query cover ranged from 84 to $99 \%$.

Analysis on 14 other Ceratobasidium sp. isolates selected based on the distribution area of each different country, showed that isolates from Indonesia were highly different from those of other countries with similiarity index (IS) ranging from 45.2 to $49.9 \%$ (Figure 3). It was clear that isolates from Indonesia has been undergoing speciation and are different from isolates from other countries.

Alignment result of nucleotide sequences of 15 Ceratobasidium sp. isolates showed high occurrence of point mutations in isolates from Indonesian, which were largely insertions and substitutions. Of the 606 total bases aligned, there were 44 bases having substitution consisting of 21 transition and 23 transversion bases.

Each of these mutations had an influence on changes in amino acids formed. Of the total 194 amino acids belonging to isolates from Indonesia, some of which had very different percentage from those of other isolates. Some amino acids of isolates from Indonesia had increased their number dramatically compared to those of other isolates, i.e. Ala, Glu, Val, Gln, Lys, and Tyr by $0.7 \%, 1.76 \%, 1.8 \%, 2.3 \%, 3.1 \%$, and $4.73 \%$, respectively, of total average. Several other amino acids had also decreased in number, i.e. Asp, Arg, Trp, Thr, and Leu by $0.11 \%, 1.53 \%, 2.07 \%, 2.25 \%$, and $4.32 \%$, respectively, of total average.

It appeared that the resulted amino acid changes had enormous influence in the process of adaptation to the environment in Indonesia. Results of the relationship analysis between isolates through the reconstruction of phylogenetic tree showed that isolates from Indonesia were on separated branches and far apart from 14 other isolates (Figure 4).

\section{DISCUSSION}

Maximum Parsimony method with Bootstrap-1000 approach classify the data based on specific characters (discrete character states) on which nucleotide sequences are used to obtain information about evolution through evolutionary data changes. The analysis result showed that Indonesia isolates were on the basal clade. Indonesia isolate showed high occurrence of point mutations, which were largely insertions and substitutions. It appeared that the resulted amino acid changes had enormous influence in the process of adaptation to the environment in Indonesia. Indonesia isolate was on separated branches and far apart from 14 other isolates. A lengthy branch, which well separating between the two groups, indicated that isolates from Indonesia had considerably evolved and it led to speciation events. Such changes in sequence through mutation was supported by the ability of the mycorrhizal itself to adapt to environmental changes as well as to its host range. The adaptability of mycorrhiza is strongly influenced by the presence of amino acid changes due to mutations that alter the function of genes which they arrange.

The reconstruction of phylogenetic tree, in addition to explaining relationship based on geographic regions, also determine the origin and history of distribution of the isolates. Trading activities of plants, fruits, and seedlings from several countries which are reported to have been infected by Ceratobasidium sp. is most likely the cause of its spreading. Indonesia is known as an importer country of orchid plant seedlings from Asian countries such as Thailand, Singapore and Taiwan (Mahfut et al., 2016), and possibly have imported seedling and fruit of apple and strawberry plants from other countries such as India and Italy that had been reported infected by Ceratobasidium sp. isolates. Proximity with Singapore in terms of geographical location is also very possible to allow distribution activities of orchids between the two countries.

This study results proved that nucleotide sequences and amino acid of Ceratobasidium sp. isolates from Indonesia were different with other isolates from another country (Asia, Europe, and America). This is thought to be a form of adaptation to the natural environment in Indonesia. Another possible result of mutations is that Ceratobasidium sp. could have the ability to infect plants while showing pathogenic characters or otherwise become mycorrhizal endophytic.

This study results clarified the MP sequence as OMF Ceratobasidium sp. isolates from Indonesia based on identification of its rDNA-ITS sequences. Furthermore, this study was expected to be the basic information beneficial for the improvement of cultivation effort as well as for the development of biocontrol agents through natural orchid protection against pathogens and diseases.

\section{CONCLUSION}

Molecular analysis based on rDNA-ITS resulted in isolate from the root of orchid plant in Yogyakarta being Ceratobasidium. These isolates showed $600-750$ bp in length DNA products located on the ITS1-5.8S-ITS4 region. The sequence products showed insertion and substitution occurances, which may result in strain diversity and possible variation in severity. Reconstruction of phylogenetic tree using Maximum Parsimony and Bootstrap-1000 approach showed that Indonesian isolates have undergone speciation and have been positioned in the cluster, which are already far apart from the other isolates.

\section{ACKNOWLEDGEMENTS}

This research was conducted with financial support from Ministry of Research, Technology and High Education, Republic of Indonesia under project of 
Doctoral Dissertation Research with grant number 89/ UN26/ 8/ LPPM/ 2016.

\section{REFERENCES}

Andersen, T. F. and Rasmussen, H. N. (1996). The Mycorrhizal Spesies of Rhizoctonia. In: Rhizoctonia Spesies: Taxonomy, Molecular biology, Ecology, Pathology and Disease Control. Sneh, B., Jabaji-Hare, S., Neate, S. and Dijst, G. (eds.). KAP, London. pp. 379-390.

Bayer, R. J., Soltis, D. E. and Soltis, P. S. (1996). Phylogenetic inferences in Antennaria (Asteraceae; Gnaphalieae; Cassiniinae) based on sequences from nuclear ribosomal DNA Internal Transcribed Spacers (ITS). American Journal of Botany 83(4), 516-527.

Currah, R. S. and Zelmer, C. D. (1992). A key and notes for the gen genera of fungi mycorrhizal with orchids, and a new species in the genus Epulorhiza. Reports of Tottori Mycological Institute (Japan) 30, 43-59.

Daryono, B. S., Joko, T. and Somowiyarjo, S. (2016). Survei Odontoglossum ringspot virus (ORSV) yang menginfeksi anggrek alam tropis di Indonesia. Jurnal Perlindungan Tanaman Indonesia 20(1), 1-6.

Doyle, J. J. and Doyle, J. L. (1987). A rapid DNA isolation procedure for small quantities of fresh leaf tissue. Phytochemical Bulletin 19(1), 11-15.

Harish, S., Kavino, M., Kumar, N., Saravanakumar, D., Soorianathasundaram, K. and Samiyappan, R. (2008). Biohardening with plant growth promoting rhizosphere and endophytic bacteria induces systemic resistance against banana bunchy top virus. Applied Soil Ecology 39, 187-200.

Johansson, K. E., Heldtander, M. U. and Pettersson, B. (1998). Characterization of mycoplasmas by PCR and sequence analysis with universal 16S rDNA primers. Methods in Molecular Biology 104, 145-165.

Kumalawati, A. D., Abdullah, S., Daryono, B. S. and Mahfut. (2011). Study on genetic diversity and conservation of orchids in Wonosadi Forest, Gunung Kidul based on molecular analysis. In: Y.A. Purwestri, (ed.), Proceedings of the $1^{\text {st }}$ International Conference on Biological Science: Advances in Biological Science, Faculty Biology UGM, Yogyakarta. pp. 7279.

Lee, M. C., Cheng, S. F., Chang, D. C. N., Chang, Y. J. and Chang, Y. S. (2010). Specific detection of mycorrhizal colonization in orchid roots by fluorescence microscopy. Journal of Biotechnology $150,496$.

Mahfut and Daryono, B. S. (2014). Deteksi Odontoglossum ringspot virus (ORSV) terhadap anggrek alam di Hutan Wonosadi, Gunung Kidul. Biogenesis 2(2), 101-108.

Mahfut, Joko, T. and Daryono, B. S. (2016). Molecular characterization molecular of Odontoglossum ringspot virus (ORSV) in Jawa and Bali, Indonesia. Asian Journal of Plant Pathology 10(1-2), 9-14.

Mahfut, Daryono, B. S. and Somowiyarjo, S. (2017). Deteksi Odontoglossum ringspot virus (ORSV) yang menginfeksi anggrek asli koleksi kebun raya di Indonesia. Jurnal Fitopatologi Indonesia 13(1), 1-8.

Mahfut, Daryono, B. S., Indrianto, A. and Somowiyarjo, S. (2019a). Effectiveness test of orchid mycorrhizal isolate (Ceratorhiza and Trichoderma) Indonesia and its role as a biofertilizer. Annual Research \& Review in Biology 33(4), 1-7.

Mahfut, Daryono, B. S., Indrianto, A. and Somowiyarjo, S. (2019b). Plant-Virus Interaction on Orchids Infected Odontoglossum Ringspot Virus (ORSV) in Bogor Botanical Garden, Indonesia. In: Harini, S., Hafsan, H., Sahara, S., Aziz, IR., Rahim, R. (eds.) Proceedings of the 1st International Conference on Science and Technology (ICoST). Makassar, Indonesia. pp 1-8.

Moreno, J. A. E., Acuña, E. A. G., Román, A. E. B., Contreras, D. J. and López, T. J. (2000). Chemical and biological fertilization of Phalaenopsis (Orchidaceae) under greenhouse conditions. Terra Latinoamericana 18(2), 125-131.

Nadarajah, K., Omar, N. S., Rosli, M. M. and Tze, O. S. (2014). Molecular characterization and screening for sheath blight resistance using malaysian isolates of Rhizoctonia solani. BioMed Research International 2014, 1-18.

Otero, J. T., Mosquera, A. T. and Flanagan, N. S. (2013). Tropical orchid mycorrhizae: potential applications in orchid conservation, commercialization, and beyond. Lankesteriana 13(1-2), 57-63.

Pannecoucque, J., Van, B. S. and Hofte, M. (2008). Characterization and pathogenicity of Rhizoctonia isolates associated with Cauliflower in Belgium. Plant Pathology 57, 737-746.

Sharon, M., Kuninaga, S., Hyakumachi, M., Naito, S. and Sneh, B. (2008). Classification of Rhizoctonia spp. using rDNA-ITS sequence analysis supports the genetic basis of the classical anastomosis grouping. Mycoscience 49(2), 93-114.

Shan, X. C., Liew, E. C. Y., Weatherhead, M. A. and Hodgkiss, I. J. (2002). Characterization and taxonomic placement of Rhizoctonia-like endophytes from orchid roots. Mycologia 94(2), 230-239.

Tanawy, E. A. (2009). Acquanting with salt tolerant endophytic bacteria isolated from rice. Plant Grown 1(2), 72-79.

Weiland, J. J. (1997). Rapid Procedure for the extraction of DNA from fungal spores and mycelia. New Prairie Press. USA. pp. 1-7.

Wu, P. H., Huang, D. D. and Chang, D. C. N. (2011). Mycorrhizal symbiosis enhances Phalaenopsis orchid's growth and resistance to Erwinia chrysanthemi. African Journal of Biotechnology 10(50), 10095-10100. 